\title{
Are push and pull factors for entrepreneurship and brain drain same? Perception of students and professionals
}

\author{
Dr. Uzma Munawar \\ Assistant Professor, Department of Education \\ Govt Sadiq College Women University Bahawalpur \\ druzmamunawar@gmail.com \\ Dr. Fariha Gul \\ Assistant Professor, Department of Education \\ University of Management and TechnologyLahore, Pakistan \\ Corresponding Author Email: f_gull13@yahoo.com \\ Dr. Shaista Noreen \\ Assistant Professor, Department of Education \\ Islamia University of Bahawalpur \\ Shaisa.noreen@iub.edu.pk
}

\begin{abstract}
Brain drain has gained attention since past few decades, this phenomenon is very apparent in Pakistan as number of people applying for immigration is increasing day by day. Although there are many measures that can be taken to reduce the process, however the best one in current local scenario is developing a safe and sound entrepreneurial niche. This study aims to provide causes of brain drain and preventive measures for this. Secondary aim of the study is to identify opinion of respondents about significance for using self-employment opportunities as solution for slowing the process of brain drain. Third this study will try to examine the relationship between factors causing brain drain and barriers preventing self-employment as career choice. Sample of the study was divided into two strata. First group consisted of 25 respondents from five high-notch professions including medicine and engineering. Second part of the sample was 20 students from doctoral (PhD), masters, medicine and engineering classes. A self developed instrumentwas be used to collect data. It is a semi-structured interview schedule for taking responses of first two segments of sample. Data was analyzed by using thematic analysis to achieve objectives of the study. It is evident that factors that are causing brain drain are almost same as those serving as barrier for adopting entrepreneurship as career choice. The officials can control brain drain by establishing entrepreneurial niche.
\end{abstract}

Key words: unemployment, brain drain, entrepreneurship 


\section{Introduction}

In previous two decades, trend of immigration has been increased by $3 \%$. People do migrate for professional growth, have better living standard and security. According to a report in Tribune 2013 about 2.7 million Pakistanis have exited from country in previous five years. Many research studies have been carried out to identify Push and Pull factors (Nunn (2005) for brain drain, while same amount of research has been carried out to explain and suggest preventive measures for brain drain. Major cause of outflow of intellectual youth is unemployment, underemployment, low living standards and social status. All of these factors can be termed as push factors for educated youth to choose immigration and work abroad. Officials through policies can control this process, one of the most effective measure can be developing entrepreneurial niche. There is positive relationship between increased unemployment ratio with increased entrepreneurial intention. So it can be stated that entrepreneurship can serve as tool for lowering or slowing process of brain drain. However, it is also observable in local context that phenomenon of entrepreneurship is lowering in local context, albeit of all incentives provided and efforts made.

It is assumed in following study that there is a correlation between increased brain drain and decreased entrepreneurship. Effort has been made to identify factors that are contributing both phenomenon and than a relationship has been established. The term brain drain was coined by royal Society of London while describing seepage of educated people from the country.This has become global problem, particularly in developing countries, where phenomenon is at peek. The research studies have shown that immigration rate of individuals holding higher/university degrees is increasing as compared to less educated people (Docquier \&Marfouk, 2006; Dumont and Lemaitre, 2005).

Although the term brain drain was assumed negative by all means, however, the trend has changed. As the studies have shown that brains drained from one country to other increases "intellectual wealth of that country" thus contributing its progress. In this perspective few new terms for studying effects of brain drain have been developed including brain gain, brain export, brain waste and brain circulation. Still there is consensus that brain drain have direct influence on economic growth as well as general prosperity of the country. The countries from where educated people migrate, availability of expert becomes a challenge that serves as major hindrance in prosperity of the country. According to a Gallop survey about sixty two percent of respondents were prone to immigration and permanently settling abroad. There are many reasons promoting phenomenon of brain drain that are identified by multiple research studies including pursuing higher education, financial stability and security. Terrorism is one major cause of brain drain (Askari, 2008), while high unemployment ratio, low salaries, lack of respect to the professionals (Raheem , 2009), unsatisfactory working conditions and political instability (Ali, 2008), discrimination in resource allocation and lack of 
merit (Shah, 23), better living conditions (Nadeem \& Ashfaq, 2010) are considered major problems as reported by literature in Pakistan. Job security, prestige and high salaries prevailing in their work settings equally attract them (Hagopian et al 2005). On the other hand entrepreneurship serve as accelerator for economic growth. The term entrepreneurship has been defined as "establishing a new business". This has a direct influence on economic growth of the country. The countries who are attracting people for live in, are also promoting entrepreneurial niche, e.g., Canada has changed its policy facilitating business immigrant with huge capital (Li, 2003). Even most of the immigrants start business as career in other countries, instead of doing business in country of origin (Wennekers \& Thurik, 1999).

There are many factors that influence adopting entrepreneurship as career choice, for example Verheul et al. (2001) has assembled these into a framework of social, psychological and demographic factors through micro, macro level business along with passion to work as entrepreneur. Similarly social identification and environment serve as an important factor in adopting entrepreneurship as career choice Nasurdin et al. (2009). Push and pull factors for brain drain are same among nurses in egypt at explored by hashish \& ashour ( 2020). A recent study carried out by poor industrial growth development are causes of migration among professionals

Several studies have documented the loss of skilled Pakistani qualified through emigration. Although precise numbers of overseas skilled Pakistanis in terms is not identified, the following statement highlights the magnitude and impact of the problem. UNESCO 127th Executive conference discussed about the highly skilled migration rate of Pakistan increased by more than 50\%from 6.1 in 1990 to 9.2 in 2000. During the period 1961-1976 the highest number of migrating skilled personnel to the US and UK, Canada came from Asia.

Habibullah Khan \& M.Shahaidul Islam discussed on the total number of Pakistani skilled workers to OECD countries (age of 25 or more or older), 85668 were immigrated with 6022 Primary level, 22458 Secondary level, and 57188 with tertiary education which shows that majority of the migrants possess tertiary qualifications. According to World Bank's dataset in Migration and Remittances Fact book 2016, in overall ranking, Pakistan stood third in South Asia (after India and Bangladesh) and sixth in the World (after India, Mexico, Russia, China, and Bangladesh) for human capital mobility. General Muhammad Safdar in his report submitted to the interior ministry reported that in the last five years more than thirty-four hundred Pakistani citizens (i.e., 4.65 percent of total registered emigrants from Pakistan during the period) have renounced their nationality, after adopting the citizenship of other countries, while another fifteen-hundred persons (i.e., 2.05 percent of total registered emigrants) are on waiting list to give up their association with the homeland (Gishkori, 2015). 
like unemployment, employment policies are the process of inclusion of the labor element in the labor market. The most basic problem of unemployment and employment in Turkey; it is artificial employment and poverty rather than open unemployment in the western sense. On the other hand; frequent economic crises have led to the loss of employees' jobs. As a matter of fact, after the last crises, approximately 10 out of every 100 people, who are called as a qualified, highly educated gold collar, lost their jobs and the official unemployment rate increased from $9 \%$ to $12 \%$. The most affected sectors are unemployed; while banking and finance and industry and service sectors are stated, there is a marked decrease in the quality of life of individuals. Another important development that attracts attention with the increasingly difficult working conditions and the economic crises is the increase of brain drain. Undoubtedly, it is possible to say that the unemployment phenomenon and the decrease in the quality of life have a significant effect on these negative developments. In this study, the reasons for going abroad and their decision to return to the country of the qualified labor force will be evaluated by logistic regression analysis in terms of pull and push factors.

\section{Objectives of the study}

The objectives of the study were as follows:

1. To identify the factors that are hindering adoption of entrepreneurship as career

2. To identify the factors that are increasing trend of immigration among individuals from different fields

3. To identify any kind of relation between push factors for entrepreneurship and pull factors for immigration

\section{Research questions}

The research questions based on objectives of the study are as follows;

1.1. What are factors that are causing hindrance in adoption of entrepreneurship as career?

1.2. What are the factors that are serving as incentives of pull factors for immigration?

1.3. Is there any relation between these push factors for entrepreneurship and pull factors for immigration?

\section{Methodology}

This part of the study deals with research design, sample and sapling technique, instrument and data analysis of the study. Qualitativewas collected by using an interview schedule.

\section{Sample and sampling technique}

Sample of the study was comprised of fifty people, who were taken from five fields including teaching, medicine, business, engineering and IT professionals. Twenty five of them were professionals working in the field while twenty five were students of these fields. Convenient sampling technique was used to collect data. The data was collected through phone calls and the prior consent was taken for recording of the call for the sake of research purpose. The recording was sent to the participants for reverification along 
with transcribed data. The language of the conversation was bilingual using both Urdu and English as per convenience of the respondents. The phone calls lasted from 15 minutes to 45 minutes. The following picture explains the sample of study. The contact details of the professionals were gathered from multiple immigration firms (who shared the data after consent from the respondent), finding the categories explained in the figure more prone to immigration, these respondents were also considered appropriate for the study as they all have had equally good chances of establishing their own business while remaining in the country. On the other hands the students from same fields were selected through convenient sampling (based on access, availability and consent to recording of conversation). The age group of the sample ranged from 27 years to 45 years old, the work experience of the professionals was minimum five years to 15 years, while the respondents from the student's strata also have work experience from less than three years to fifteen years in their respective fields of further studies and were also seeking better jobs. The following figure explains the sample of the study;

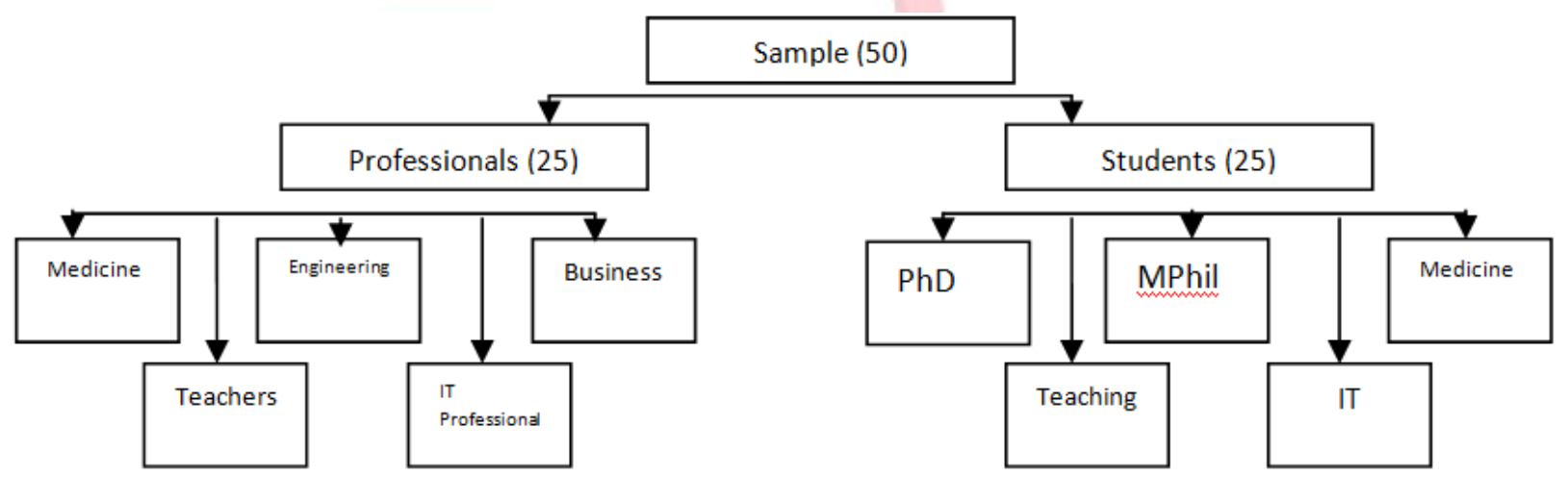

Figure 1. Sample of the study

\section{Instrument of the study}

After extensive literature review, a semi-structured interview schedule was developed. This was validated through expert opinion and necessary changes were made, two statements were removed, while probing statements were added. This instrument was pilot tested on three individuals including one professional and two students, who were not part of the sample. After piloting the statements were rephrased in order to make them simpler and more understandable.

\section{Data collection}

Data was collected through phone calls. For this purpose, prior consent was taken explaining purpose of interview, as well as clarifying that it will be recorded. In addition to this appointment for phone call was also made. At second step, interviewees were contacted at given time and interview was carried out. Their responses were repeated at the end of interview in order to get census on what they have said and what is understood. 
Afterwards, the recording along with transcription was also shared with the respondents. In total 50 interviews were carried out, twenty five from professionals while twenty five were taken from graduate and doctoral students of this field as they were prospect job seekers of these fields.

\section{Data Analysis}

Data was transcribed later and analyzed through content analysis. Respondents were categorized in two groups and "P" for professionals while "S" stands for students. The interview was composed of two basic questions i.e., pull and push factors for brain drain and low tendency of adopting entrepreneurship as career choice. Themes emerged from responses of interviewees helped in dividing barriers in following four categories;

1. Social reasons/barriers

2. Personal reasons/barriers

3. Political reasons/barriers

4. Financial reasons/barriers

The following graph explains the percentage of respondents on aforementioned categories;

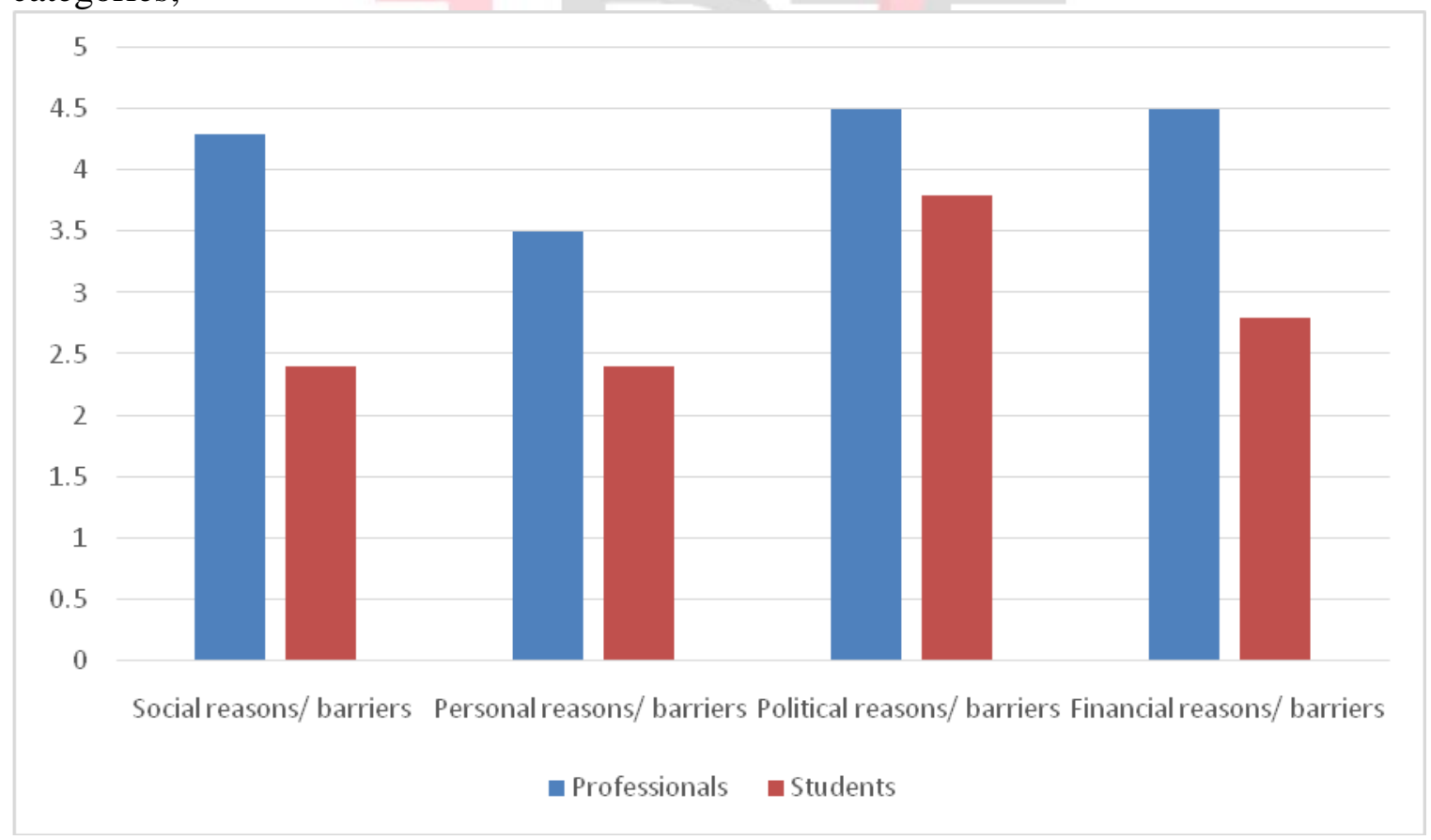

Graph 1. Reasons to higher tendency towards immigration

The respondents from professional strata seems to face more issues and have more barriers in adopting entrepreneurship as career choice instead of going abroad. The comparison shows that the strata from students though have similar issues as described 
the professionals, however, their perceived intensity seems relatively less, the reason behind this might be the difference of age and exposure to professional experience.

The respondents were asked about reasons of educated people for leaving country. The abovementioned themes could are further explained by quoting responses from the data. For example one response from P1 was;

"People particularly the educated ones apply immigration because here they do not have chances for professional growth".

This is general assumption among all categories of respondents that they have very low chances of professional growth, and many people apply for immigration due to this. One (P10) stated

"Being in the field of engineering I know that there are few chances for higher studies, so many people in other fields seek career abroad because they want to excel in their field".

Similar statement was given by students, as one (S3) stated that

"The people prefer to work in other developed countries because they are paid according to their caliber and work (not less than qualification as happen here)".

Second statement was about measures that can be taken to reduce or control phenomenon of brain drain. The respondents suggested that government should put effort to develop policies regarding employment and merit. For example, P13 stated that,

"Policies should be developed for promoting merit"

Similarly P1 declared that

"Employment opportunities should be increased"

Another professional (P3) stated

"Clear cut policies should be made for recruitment, employment and retirement for upcoming youth"

While another different respond from S2 was

"The students should be provided with facility to mentorship so that they can decide their future career options"

They were asked that can entrepreneurship help in reducing phenomenon of brain drain. Many of them stated that it can be a partial solution, while others completely rejected the idea. The frequency of respondents can be figured out from the following chart; 


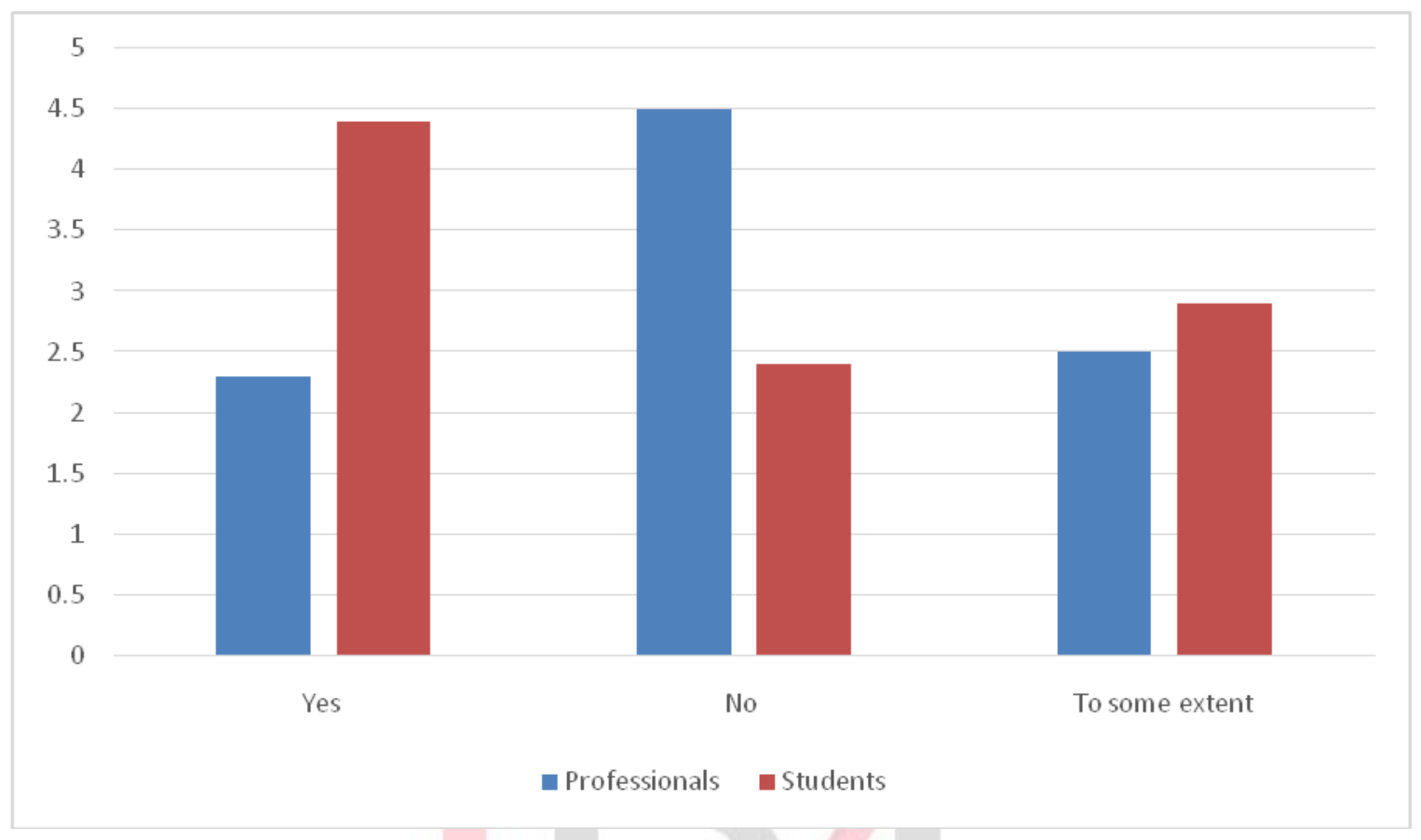

Graph 2. Is entrepreneurship better option to reduce the trend of immigration

The results indicate that the professionals are against the idea of using entrepreneurship as panacea for reducing immigration trends. On the other hand, students seem more hopeful about this strategy, the following sample responses may explain the reasons given after probing. For example P6 stated

"No, it cannot be assumed as a good idea because everyone is not business stuff".

Similarly (P 22) stated that

"Business cannot replace brain drain because we live in job oriented society and do not adopt business as a career"

Responses of students were almost similar to those of professionals, for example S16 stated

"Self-employment as a career choice is better option, however it cannot be adopted

Similarly P19 stated that;

"It can only serve as a solution, if people are given vocational training and they have expertise in a vocation"

Similarly S6 added that

"If we (the government) want self-employment (entrepreneurship) as a tool for lowering ratio of brain drain than efforts should be made to develop positive attitude towards this" One P3 also stated

"That it cannot serve as permanent solution, however, it is a better option". 
At the end they were asked that why people prefer to immigrate over self-employment, the responses were almost similar to that of first question. The following chart presents the frequency of responses in each category;

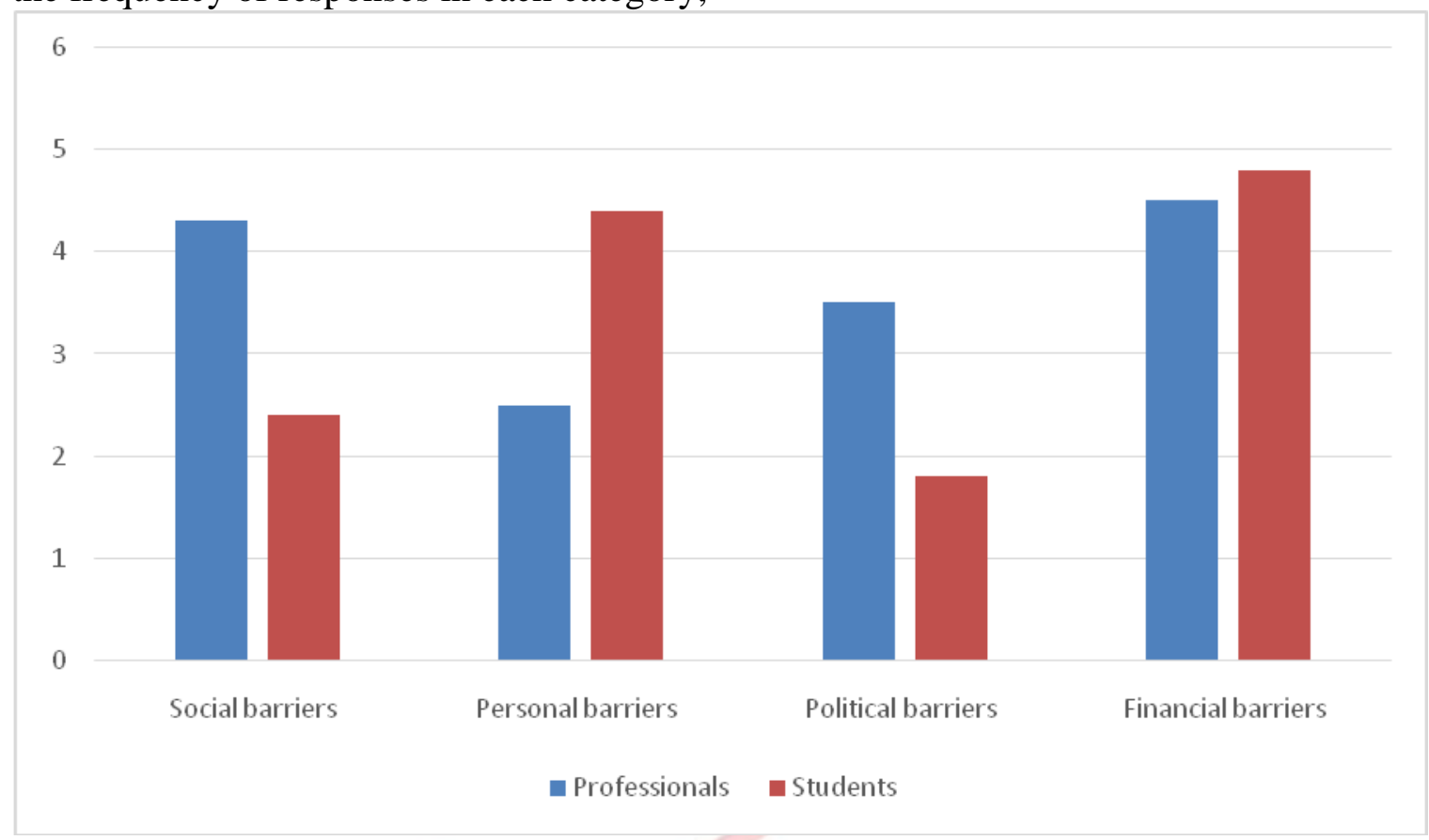

Graph 3. Reasons for not choosing entrepreneurship as career choice

For example P18 stated

"Mainly people do not prefer adopting business because they do not have finances to start a business"

Similarly S19 stated

"In society we do not have value of money making so people do not prefer to go in business field"

Another response from S8 was

"We are a job oriented society, we are prepared to get jobs not to do business"

While another (P25) stated

"People do not take (financial) risk"

Another statement from S21 was

"People do not want to work hard, while being an entrepreneur is 24 hours job so they prefer employment"

P1 stated that

"Government has not provided sufficient and flexible policies for starting a business" 


\section{Discussion}

From the responses it is clear that causes ofbrain drain are almost similar to that of obstacles for adopting entrepreneurship as career choice. The people do migrate because of unemployment, under-employment, personal factors (family reunion, professional growth), better living standards, peace and security. While some other reasons also include political instability which in turn lead towards unstable policies, corruption, lack of satisfactory employment regulations, low salaries and low chances of growth. Same reasons have been described as obstacles for adopting entrepreneurship as career choice, including personal factors (lack of training, low self esteem), lack of financial resources, ambiguous policies, corruption, living standard, political instability and increased terrorist activities.

For example the personal factor is perceived self-esteem and behavioral control that lead towards adoption of entrepreneurship as career Autio et al (2001). According to respondents' point of view, environment is not supportive for establishing or running a business. Another important factor described by same author is support from family and friends for running a business or adopting it as full time career. While in local context it is missing, although expectations are there,however, many a times people are encouraged to get a job. Similarly, cultural values are also important aspect that influences entrepreneurial orientation as described by Pruett et al. (2009). In local context it is assumed that if a person gets higher education, he/she must go for good job rather than starting business.Another response that came very frequently from interviewee was, that they were afraid of doing anything other than job. People think that they do not have sufficient training or required skill to establish a business. The respondents also stated that it is necessary to develop attitude of people towards self-employment through various programs and seminars. Same thing has been suggested by Nasurdin et al. (2009) for attracting more people to adopt business as career choice. People were also afraid that they do not have skills required for establishment of business. They were probed further about types of skills they required, the response was very clear, stating that business/entrepreneurship skill training is mandatory for establishment of a business. This has been supported by research study carried out by (Karlan \& Martin, 2006). Financial resources were also stated as a problem, respondents stated that to establish a business funds are required. Many times people do not have sufficient money. That is why they do not adopt business as career choice same has been reported by Grilo \& Thurik, (2005). People also did complaint that official policies are not supportive for establishment of business, there are many problems from taxation to registration and day to problems which cannot be dealt due to complex official procedures. The previous research studies also have provided support to this notion that government policies has direct influence on growth of entrepreneurship. This relation can be described through following diagram; 


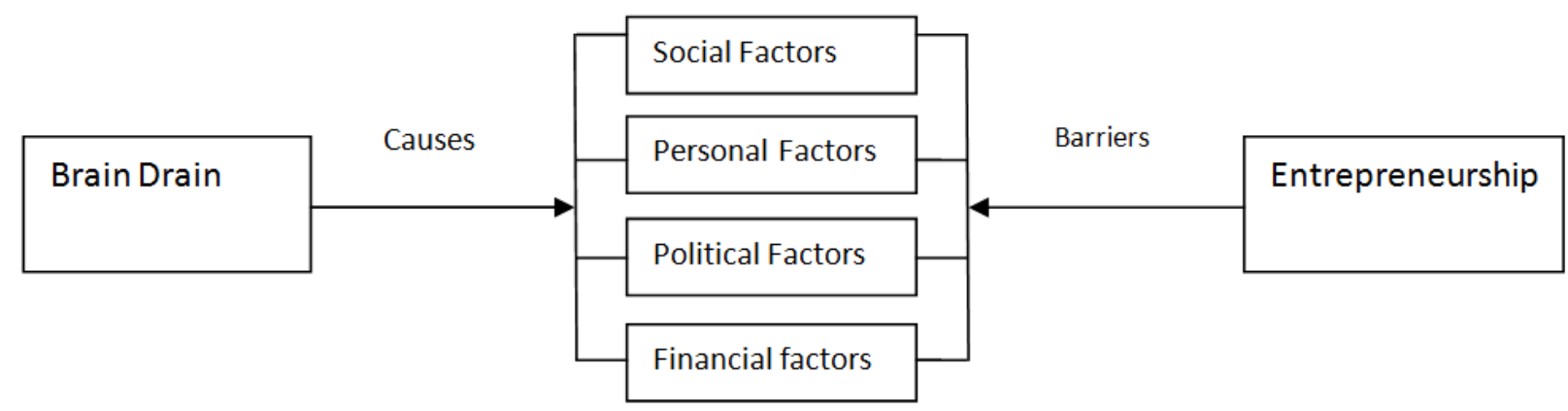

Figure 2. Causes and Barriers for Brain drain and Entrepreneurship

Now if these factors and sub factors are related to each other, they can be turned into single framework. The people are afraid of choosing entrepreneurship as career choice because they lack training, so they prefer to go abroad and get job relevant to their personal skills with high outcome. Similarly, the financial factor lead towards immigration in spite of entrepreneurship, people do not have money to put into a business which will start giving back in shortly. On the other hand when they get job abroad, they immediately start earning good money so they prefer to go abroad inspite of starting a business. In addition to this investment in visa, ticket and lodging give pay back soon, while starting a business do not. Similarly increased terrorism and lack of peace have also motivated people to go abroad, this is same reason that has prohibited people for thinking about establishing or running a business. Social values are also major influential factor play role, people who migrate get higher living standard due to increased income, on the other hand in start of business many times it is not possible to get sufficient return, thus lowering living standard, this also serve as motivational factor to go abroad and no to adopt entrepreneurship as career choice. Political instability, lack of proper rules and regulations are also major cause, in addition to this corruption also serve as enzyme for both constructs. On the basis of these relations, it can be stated that factors that are promoting are same as those hindering entrepreneurship. The results can be summarized in following diagram;

\section{References}

Branna, S. (2006). Causes and its impacts on Africa, Thesis presented at Palacky University ,Geography Department.

Docquier, F. \& Marfouk, A. (2006). International migration by educational attainment (1990-2000), in C. Ozden and M. Schiff, eds., International migration, remittances and the brain drain, Chapter 5, Palgrave-Macmillan 
Dumont, J.C. \& Lemaitre, G. (2005). Counting immigrants and expatriates in OECD Countries: a new perspective, OECD Social Employment and Migration Working Papers,No. 25, Paris: OECD Directorate for Employment, Labour and Social affairs Grilo, I. \& Thurik, A.R. (2005). Latent and Actual Entrepreneurship in Europe. International Entrepreneurship and Management Journal, 1 (4), pp. 441-459.

Hagopian, A., Ofosu, A., Fatusi, A., Biritwum, R., Essel, A., Hart, L. G. \& Watts, C. (2005). The Flight of Physicians from West Africa: Views of African Physicians and Implications for Policy. Social Science and Medicine 61 (8): 1750-60

Karlan, D. \& Valdivia, M. (2006). Teaching Entrepreneurship: Impact of Business Microfinance Institutions and Clients. Yale University Economic Growth Center working paper

Li, P.S. (2003). Chinese Investment and Business in Canada: Ethnic Entrepreneurship Reconsidered. Pacific Affairs, Vol. 66, No. 2 (Summer, 1993), pp. 219-243.

Mohsin, A. Reasons of brain drain in Pakistan. Available at: http://www.einfopedia.com/reasons-of-brain-drain-in-pakistan.php

Nasir, N.\& Dr. Mohammed, A. (2004). Brain Drain Causes and Implications. The Dawn, Available at:http://archivesdawn.com/2004/10/18/ebr8.html

Nasurdin, A.H., Ahmad, N.H. \& Lin, C.E. (2009). Examining a Model of Entrepreneurial Intention among Malaysians Using SEM Procedure. European Journal of Scientific Research, 33, 365-373.

Nunn, A. (2005). The 'brain drain' academic and skilled migration to the UK and its impacts on Africa report to the AUT and NATFHE, Policy Research InstituteLeeds Metropolitan University Retrieved from www.leedsmet.ac.uk/lbs/pri

Raheem, (2009). The impact of brain drain on Pakistan's economy", Daily Times.

Wennekers, S. \& Thurik, A.R. (1999). Linking entrepreneurship and economic growth. Small Business Economics13, November. 1, pp.27-55

The Express Tribune Web desk, December 23, 2013 http://tribune.com.pk/story/649347/brain-drain-2-7m-pakistanis-have-exited-country-inlast-5-years/

Wajid, T., Rubina, K. \& Majid, A.T. (2011). Brain Drain of Doctors; Causes and Consequences in Pakistan Muhammad World Academy of Science, Engineering and Technology, Vol:5 2011-03-27 